\title{
A Transtextual Approach to Lexicographic Functions*
}

\author{
Rufus H. Gouws, Department of Afrikaans and Dutch, University of
}

Stellenbosch, Stellenbosch, Republic of South Africa (rhg@sun.ac.za)

\begin{abstract}
The development of theoretical lexicography clearly indicates a movement towards a more general recognition of the role of lexicographic functions. A consistent application of lexicographic functions has a major influence on the contents of dictionary articles but also on the data distribution and even the typological classification. In the discussion of lexicographic functions, the emphasis has primarily been on the central list of dictionaries. This article proposes an approach where outer texts are also selected and compiled in order to make an active contribution to achieving the lexicographic functions of a given dictionary. A distinction is made between function-adhering and non-function-adhering outer texts. The function-adhering outer texts can further be divided into integrated and non-integrated function-adhering outer texts. With reference to the data distribution programme of a dictionary, it is suggested that in the planning of every dictionary, provision should be made for a function allocation programme. This will ensure that the identified functions of a given dictionary will be realised in both the central list and the outer texts.
\end{abstract}

Keywords: BACK MATTER TEXTS, CENTRAL LIST, COGNITIVE FUNCTION, DATA DISTRIBUTION, FRAME STRUCTURE, FRONT MATTER TEXTS, FUNCTION ALLOCATION PROGRAMME, FUNCTION-ADHERING OUTER TEXTS, FUNCTIONAL TEXT PARTS, INTEGRATED FUNCTION-ADHERING OUTER TEXTS, LEXICOGRAPHIC FUNCTIONS, NONFUNCTION-ADHERING OUTER TEXTS, NON-INTEGRATED FUNCTION-ADHERING OUTER TEXTS, OUTER TEXTS, TEXT PRODUCTION, TEXT RECEPTION, TRANSTEXTUAL APPROACH

Opsomming: 'n Transtekstuele benadering tot leksikografiese funksies. Die ontwikkeling van die teoretiese leksikografie toon 'n duidelike beweging in die rigting van 'n groter erkenning aan die rol van leksikografiese funksies. 'n Konsekwente toepassing van leksikografiese funksies het ' $n$ ingrypende invloed op die inhoud van woordeboekartikels maar ook op die dataverspreiding en selfs op die tipologiese klassifikasie. Tot dusver was die klem in die gesprek oor leksikografiese funksies veral op die sentrale teks van woordeboeke. Hierdie artikel bepleit ' $n$ benadering waar die buitetekste ook gekies en saamgestel moet word om aktief by te dra tot die bereiking van 'n bepaalde woordeboek se leksikografiese funksies. 'n Onderskeid word gemaak tussen funksienakomende en niefunksienakomende buitetekste. Die funksienakomende buitetekste kan op hulle beurt weer onderverdeel word in geïntegreerde en niegeïntegreerde funksienakomende tekste. Na aanleiding van die dataverspreidingsprogram van woordeboeke word voorgestel

* This article was presented as a paper at the Thirteenth International Symposium on Lexicography at the University of Copenhagen, Copenhagen, Denmark 3-5 May 2007. 
dat daar in die beplanning van elke woordeboek ook voorsiening gemaak word vir ' $n$ funksietoekennende program. Dit sal verseker dat die geïdentifiseerde funksies van ' $n$ bepaalde woordeboek in sowel die sentrale teks as die buitetekste verwerklik word.

Sleutelwoorde: AGTERTEKSTE, BUITETEKSTE, DATAVERSPREIDING, FUNKSIENAKOMENDE BUITETEKSTE, FUNKSIETOEKENNENDE PROGRAM, FUNKSIONELE TEKSDELE, GEÏNTEGREERDE FUNKSIENAKOMENDE BUITETEKSTE, KOGNITIEWE FUNKSIE, LEKSIKOGRAFIESE FUNKSIES, NIEFUNKSIENAKOMENDE BUITETEKSTE, NIEGEÏNTEGREERDE FUNKSIENAKOMENDE BUITETEKSTE, RAAMSTRUKTUUR, SENTRALE TEKS, TEKSPRODUKSIE, TEKSRESEPSIE, TRANSTEKSTUELE BENADERING, VOORTEKSTE

\section{Introductory remarks}

The development of theoretical lexicography shows a number of significant trends. The lexicographic practice developed in a pre-theoretical era and theoretical lexicography has to be regarded as a relative late-comer, complementing practical lexicography. One of the important early phases in the development of theoretical lexicography was heralded by the publication of Zgusta (1971). This phase of theoretical lexicography had a strong linguistic bias with the focus primarily on the linguistic contents of dictionaries. This linguistic approach had a wide-ranging influence, among others also on an aspect like typological classification. At this stage, theoretical lexicography was primarily practised by linguists and taught in linguistic or language departments. Lexicography was seen as a subdiscipline of linguistics.

In the course of time it became clear that language is the object of linguistics and dictionaries are the objects of lexicography. Consequently lexicography was no longer seen as subdiscipline of linguistics but as a discipline in its own right (cf. Wiegand 1998: 33, Tarp 2000: 192, Hartmann and James 1998, Bergenholtz and Tarp 2005). Although the linguistic contents of dictionaries remained an important aspect of theoretical lexicography, there developed a keen interest in the packaging of this linguistic data and a shift in emphasis towards the structure of dictionaries. The user-driven approach led to yet another phase in the development of theoretical lexicography, i.e. lexicographic functions. This development in theoretical lexicography has led to numerous changes in the way lexicographers speak about dictionaries and, hopefully, in the way people compile dictionaries. Unfortunately the full consequence of these changes, and this applies to the emphasis on dictionary structures as well as the subsequent emphasis on lexicographic functions, has not yet been realised - neither in theoretical lexicography nor in lexicographic practice. One such example where the implications of lexicographic functions have not yet been applied in a consistent way is the typological classification of dictionaries where the traditional typological models are still largely utilised. Naturally, many of these classifications are still valid and should remain in use. As an example: there is not really a classificatory substitute for etymological dictionary and even the distinction 
between diachronic and synchronic dictionaries, albeit a linguistically-driven distinction, still has a definite value in modern lexicography. But a functional approach to dictionary typology should at least see the envisaged functions of a dictionary being displayed as a subtitle or another kind of entry on the cover and title page of a printed dictionary or on an opening screen of an electronic dictionary. In doing this, lexicographers do not have to confront their users with technical terms like text production, text reception or cognitive function, but a traditional title may be supplemented by an entry like: "helping with the writing/understanding of texts". The implications of a functional approach for typological classification is a matter for a different article. The idea has been discussed briefly in Hartmann (1987), Tarp (2002) and, in slightly more detail, in Gouws (to appear).

An illustration of where developments in lexicographic structures have not yet been applied in an optimal way in the lexicographic practice regards the frame structure. Although dictionaries more often than not employ front and back matter texts as venues for a more comprehensive data distribution, these outer texts are too often selected on either an arbitrary or a traditional basis; traditional in the sense that it exclusively relies on the pattern followed in other dictionaries without any innovative approaches in terms of new types of outer texts or a new way of presenting data in these texts. Too seldom they are employed to enhance the realisation of the lexicographic functions of a specific dictionary.

In this regard dictionary users should be introduced to the use of functions as more than merely nice-to-haves or a presentation of additional data not as relevant to the dictionary as the data included in the central list. Lexicographers should employ their own dictionaries to familiarise users with the functions of the dictionary, as realised in both the central list and the outer texts. A front matter text like the user's guide should be employed to explicate the nature of e.g. dictionary structures and lexicographic functions. Nielsen (2005: 137) states the twofold purpose of the user guide of a dictionary as follows:

First of all, it introduces the user to the structure and contents of the dictionary so that he may have the greatest possible benefit of its data. Secondly, it explains the fastest and easiest way to the data and hence the information sought.

This needs to be seen as criticism against the way in which many lexicographers do not use the user guides of their dictionaries. Although Nielsen does not mention anything about lexicographic functions in this paragraph, he later criticises the lack of a discussion of lexicographic functions in the user's guide of the majority of dictionaries when saying that "user's guides whose texts are explicitly based on dictionary functions are few and far between". He also makes a plea for an explicit link between the functions of a dictionary and the information in its user's guide (Nielsen 2005: 138).

The approach of lexicographic functions needs a much more aggressive application in the outer texts of dictionaries, especially when considering Tarp 
(2000: 198) who maintains that:

The functions are the very essence of lexicography. The functions constitute the leading principle of all dictionaries. Everything in a dictionary is to a greater or lesser extent influenced by its respective functions. Neither the contents nor the form of a dictionary can be conceived without taking the functions into account. It is possible to outline an integrated model of a lexicographic reference work on the basis of the functions.

In the remainder of this article the emphasis will be on the way in which a consistently applied functional approach could influence the theory regarding outer texts as well as the selection of outer texts and the presentation of data in these texts. However, first some comments will be made regarding the status of outer texts, especially the user's guide text, as targets of dictionary consultation procedures.

\section{Realising the importance of outer texts}

When speaking about outer texts metalexicographers emphasise their importance whilst practical lexicographers often maintain that these texts, especially the users' guidelines text presented in the front matter section of dictionaries, are rarely consulted by dictionary users. Looking at the aims of dictionaries of languages used in Central Africa, Busane (1990: 22) states that by looking at the prefaces and introductions of dictionaries one can obtain information about the audience at whom the dictionary had been directed. He goes further by referring to Haugen (1985) who used this method to determine the goals envisaged by Scandinavian lexicographers and who indicated that by reading numerous introductions to dictionaries one can learn what the purposes were "that animated lexicographers to undertake their often tedious and always underpaid tasks". Busane gives examples from front matter texts identifying the intended target users. Even though outer texts may be compiled in such a way that they have a user-friendly nature, a dictionary culture is needed to ensure the use of outer texts. In this regard Busane (1990: 28) says:

Many introductory pages (are) usually allocated to grammatical sketches of the language concerned without the knowledge of which it is deemed hazardous to use the dictionary successfully. We believe, however, that these sections and introductory explanations are not sufficient provisions for a user-friendly product. Dictionary users are known to allocate little time to the study of these prefatory matters.

The user also comes to the fore in Herberg (1989: 751) who discusses problems regarding the prefaces of dictionaries and who indicates, also in this regard, the importance to distinguish between different user groups, i.e. laypersons and scientists, so that the dictionary can respond to the demands of both these user groups. He continues that the prefaces of dictionaries should be compiled as 
purposeful and user-oriented as possible. According to him, the nature of the preface of a dictionary depends largely on the type of dictionary. Because dictionary types should be compiled for specific users, one can deduce that the target user group, their needs and reference skills should also play a decisive role in the planning and compilation of outer texts.

When Herberg's approach (that the prefaces of dictionaries should be compiled as purposeful and user-oriented as possible) is followed, and in spite of the scepticism of Busane shared by many others, the status of outer texts as venues of dictionary consultation may not be eschewed. In this regard promising confirmation comes from the Danish phraseological dictionary Ordbogen over Faste Vendinger and the Danish music dictionary Den Danske Musikordbogen, both internet dictionaries. An analysis of the log files of these two dictionaries indicates unequivocally that users do consult the outer texts. Over a brief period of time, an average of at least five percent of the daily users of the phraseological dictionary consulted the various outer texts. Similar results were obtained from the use of the music dictionary. ${ }^{\dagger}$ Interestingly enough, the log file indicated that the preface of the phraseological dictionary has more hits than the user's guide. This has implications for lexicographers believing that the preface does not have a role to play in a dictionary. Bearing in mind that the number of consultations of outer texts is given as a percentage of the total daily consultation count, one can expect that the actual percentage of users who consult the outer texts, albeit not on a daily basis, could be considerably higher. The same user will consult the dictionary more than once, but will not necessarily use an outer text every time. These results put the responsibility on the shoulders of the lexicographer to utilise a frame structure and to include the types of outer texts needed by the target users of the envisaged dictionary. The lexicographer should not only provide outer texts with satisfactory contents, but should also ensure that the functions of the dictionary prevail in these outer texts.

\section{Changes in the theoretical approach to outer texts}

Wiegand (1988: 844) argues that dictionaries are utility products and that they have a genuine purpose. Bergenholtz, Tarp and Wiegand (1999: 1776) take the notion of the genuine purpose of dictionaries further by saying that the genuine purpose of a dictionary consists in the possibility to retrieve information from the lexicographic data about the subject matter of the dictionary. The outer texts of a dictionary are also classified in terms of the genuine purpose, distinguishing between integrated and non-integrated outer texts. Outer texts from which it is possible to retrieve information that helps to fulfil the genuine purpose of a dictionary are called integrated outer texts. This important distinction between integrated and non-integrated outer texts, a distinction based on the role of the outer texts regarding the fulfilment of the genuine purpose of a dictionary, has not yet found a parallel in the function-based theoretical ap- 
proach. Negotiating the point of view of Tarp (2002: 198) that everything in a dictionary is to a greater or lesser extent influenced by the functions of the dictionary, it is somewhat disturbing that the theoretical discussions of lexicographic functions have not yet given due acknowledgement to the extent of the nature and scope of the implications of lexicographic functions for other texts in the dictionary besides the central list. Outer texts should also be selected and compiled in order to achieve the function(s) of a given dictionary. A distinction that needs to be made is that between a different kind of integrated and nonintegrated outer texts, i.e. outer texts which are integrated or not integrated into the function(s) of a dictionary (cf. Gouws and Steyn 2005).

Within the category of outer texts of a given dictionary, a distinction should be made between those texts that do and those that do not enhance the information transfer in the dictionary. Here the notion of information transfer refers to texts that are consulted by users as part of the overall dictionary consultation process, and not those texts that, relevant as they may be, contain data that does not constitute a target of a typical dictionary consultation procedure, e.g. the imprint or a text in which the lexicographer expresses thanks to sponsors, colleagues, family, etc.

Wiegand (1989: 425) distinguishes between functional and non-functional text segments, indicating that the difference lies in the genuine purpose of the segment. A functional text segment is a part of a dictionary article, consisting of a form and at least one genuine purpose. Here the word functional should not be confused with lexicographic functions. Hausmann and Wiegand (1989: 330) indicate that the front matter of a dictionary as a whole is not a functional part of the dictionary, but rather an arbitrary set of functional text parts. They refer to the different front and back matter texts as functional text parts. Yet again, functional should not be seen as referring to a lexicographic function. According to them, front matter texts like the title, the table of contents and the imprint are all functional text parts. Following Wiegand's definition of functional text segments, one could go further and take this notion from the level of the text segment to the level of the text part by arguing that a functional text part, here an outer text, would be a text part with a form and at least one genuine purpose. This genuine purpose does not necessarily have to agree with the genuine purpose of the dictionary as a whole.

Within a lexicographic function approach, a distinction needs to be made between Wiegand's functional outer texts, i.e. outer texts that have a genuine purpose, and function-adhering outer texts, i.e. outer texts by means of which a given lexicographic function can be achieved. Within any given dictionary, the function-adhering outer texts should be distinguished from non-functionadhering outer texts, i.e. the imprint, the list of staff and contributors, etc. Function-adhering outer texts can be divided into integrated function-adhering outer texts and non-integrated function-adhering outer texts. The integrated function-adhering outer texts are integrated into the lexicographic functions of the central list of the given dictionary. This implies that the functions identified 
for the specific dictionary are not restricted to the central list, but go beyond the borders of this text to allow a transtextual function approach. The distinction between integrated and non-integrated function-adhering outer texts allows the lexicographer to include outer texts that assist users in achieving a wellidentified lexicographic function, albeit that this function has not been identified as having to prevail in the central list of the dictionary. Such an approach adds a new dimension to the notion of polyfunctional dictionaries, i.e. that all the functions do not have to be achieved in the central list of such a dictionary and that the central list is not the only venue for the realisation of functions.

\section{Putting new developments in lexicographic theory to practice}

In current lexicographic practice, the awareness level of lexicographic functions in the outer texts of dictionaries is not satisfactory. Too often it still seems as if the inclusion of outer texts has been done on a random basis without negotiating the genuine purpose of a given dictionary. Tarp (2002: 16) says:

According to the functional theory of lexicography, no data whatsoever should be included in any dictionary if it cannot be argued on the basis of its respective functions.

In some dictionaries, a functional and even a transtextual functional approach prevails without the user being convinced that a lexicographic function approach had been planned for the dictionary. A more deliberate application of lexicographic functions in the outer texts and an unambiguous selection of these texts and their contents in terms of the identified lexicographic functions will enhance the information transfer in a dictionary.

Albeit that a transtextual functional approach does not always prevail, outer texts, especially the user's guide, have been put to use to explicate the functions of a given dictionary and in so doing have accommodated the results of metalexicographic research; $c f$. the way in which the prevailing functions of the dictionary are introduced in the internet version of the English Dictionary of Accounting:

A dictionary is an aid, a tool. Like other tools, some dictionaries have one function and others have several functions. The English Dictionary of Accounting has several functions. ...

The tool called a dictionary can be used in connection with specific communication-related problems or in connection with a wish to learn more....

Communication-related information serves to help you solve problems that may occur when you write or when you read English accounting texts.

Help to write English texts

When writing accounting texts in English you may not be sure about the correct spelling of a word. This can be found in the presentation of the headword. ... 
Help when reading English texts

When you read an English accounting text, you may be in doubt as to the correct meaning of a term. ...

Help to acquire knowledge about accounting matters

The functions described above serve as help to solve problems that are related to specific types of communicative acts. In addition, this Dictionary can also be used if you want to learn more about something, i.e. in connection with knowledge-oriented problems.

Introducing the lexicographic functions of a given dictionary in its user's guide can be regarded as a first step in the utilisation of outer texts to enhance the realisation of lexicographic functions. A next step would be the deliberate choice of outer texts on the basis of these texts adhering to the lexicographic functions identified for the given dictionary and the announcement of these functions, and the transtextual functions in the user's guide of the dictionary.

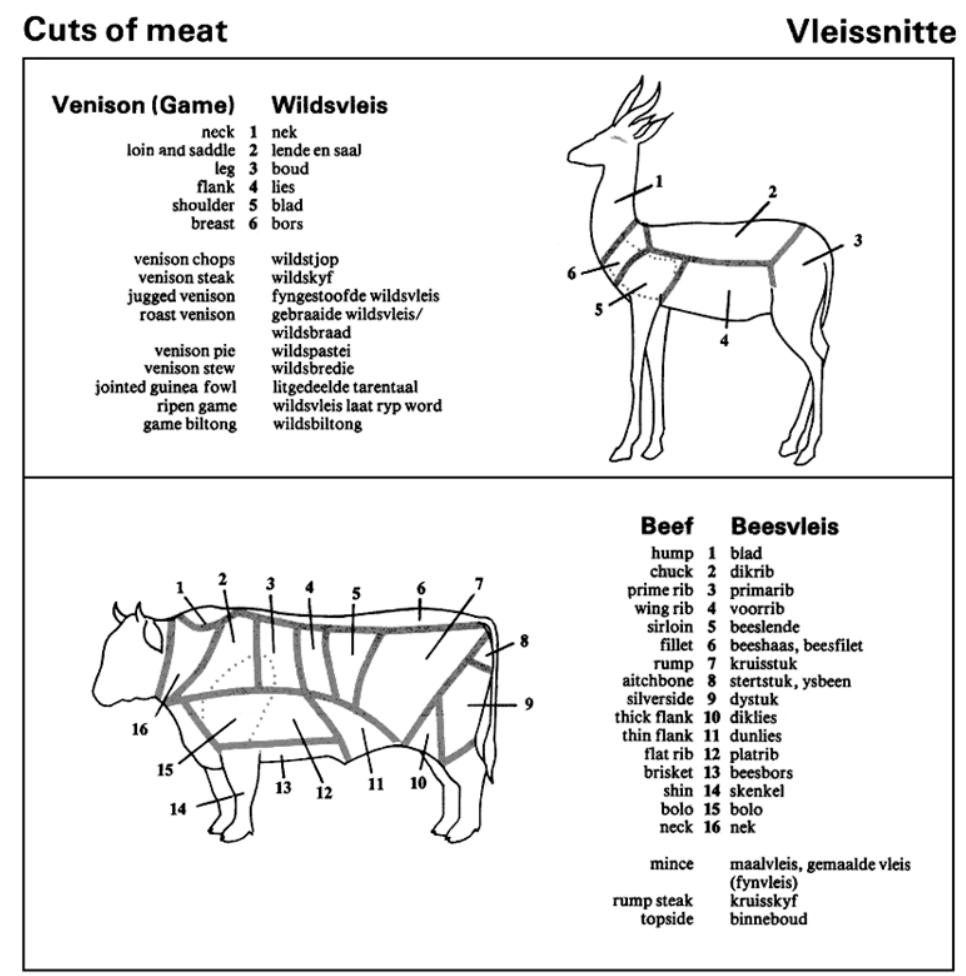

The preface of the Afrikaans-English/English-Afrikaans bilingual dictionary Reader's Digest Afrikaans-Engelse Woordeboek/English-Afrikaans Dictionary gives no indication of the envisaged target user or the lexicographic functions of the dictionary although it explicitly refers to the assistance users get in "using the right word" and "understanding the other language", i.e. text production and 
text reception respectively. When one looks at the central list, it soon becomes clear that this dictionary primarily has a communication function with the emphasis especially strong on text reception and to a lesser degree also on text production. The back matter section of this dictionary contains a range of outer texts (cf. Gouws 2004). Some of these texts maintain the communication functions of the central list and help to establish a transtextual application of lexicographic functions. Some other back matter texts also adhere to a lexicographic function albeit that they clearly deviate from the functions typically prevailing in the central list of the dictionary. A back matter text presenting the different cuts of meat for beef, pork and mutton, along with pictorial illustrations to show where each cut is found on the relevant animal, typically has a cognitive function. The same applies to a back matter text presenting a map of the world with a wide-ranging selection of oceans, continents, countries, capital cities, etc. indicated on this map. These outer texts with their cognitive function are not integrated into the functions of the central list of the dictionary, but being function-adhering outer texts, they increase the polyfunctional value of the dictionary.

Awareness of the data distribution structure (cf. Bergenholtz, Tarp and Wiegand 1998), the frame structure (cf. Kammerer and Wiegand 1998) and the notion of a dictionary being a carrier of text types (cf. Wiegand 1996) has given lexicographers the freedom to go beyond the central list in the presentation of data. With regard to the structure and contents of dictionaries, the required response has been obtained, but not yet with regard to lexicographic functions. A stronger interaction in terms of lexicographic functions between outer texts and central list is needed. In this regard lexicographers should, as part of the dictionary conceptualisation plan, negotiate the possibility of a function allocation programme, similar to the data distribution structure, to ensure that all the functions identified for a specific dictionary will be realised and that both outer texts and central list participate in the realisation of these functions. A lack of a well-planned function allocation programme too often results in dictionaries with text production as function to have back matter sections dominated by texts with a text reception or cognitive function. These texts are important, but represent a secondary function of the dictionary. Outer texts are not only there for the secondary functions, but should also be employed for a realisation of the primary function(s). For a text production function, back matter texts like Writing a letter, Forms of address, Collocations, etc. can play an important role as function-adhering integrated outer texts. Once the primary functions have been achieved, the importance and value of function-adhering non-integrated outer texts may not be underestimated. In this regard the introduction of a cognitive function in outer texts in a dictionary where communication functions prevail in the central list can enhance the status of the dictionary as a response to the needs of a specific target user group. The function allocation programme should determine the textual venues where both primary and secondary functions should prevail. 


\section{In conclusion}

As a carrier of text types, a dictionary displays different structures, contains different data types and can assist in achieving one or more lexicographic functions. In the same way in which metalexicographers argue in favour of the word book structure of a dictionary, focusing not only on the central list but also the outer texts in the front and back matter sections, metalexicographers who favour a lexicographic functions approach should work towards a situation where dictionaries are characterised by their transtextual function approach, with functions prevailing in different texts of the carrier of text types. Introducing the concepts of function-adhering outer texts and the distinction between integrated and non-integrated function-adhering outer texts, defined in terms of their relation to the identified functions of the given dictionary, this article favours a wide-ranging application of lexicographic functions across textual borders in order to enhance the success of typical dictionary consultation procedures. From a functional perspective, the typical comment of outer texts should be: the truth is out there.

\section{Endnote}

$\dagger \quad$ Information obtained from Henning Bergenholtz — personal communication.

\section{Literature}

\section{Dictionaries}

Bergenholtz, H. and V. Vrang. 2007. Ordbogen over Faste Vendinger. http://www.idiomordbogen.dk. Bergenholtz, I. 2006. Den Danske Musikordbogen. http://musikordbogen.dk/musik/.

Grobbelaar, P. et al. (Eds.). 1987. Reader's Digest Afrikaans-Engelse Woordeboek/English-Afrikaans Dictionary. Cape Town: The Reader's Digest Association, South Africa (Pty) Ltd.

Hartmann, R.R.K. and G. James. 1998. Dictionary of Lexicography. London: Routledge.

Nielsen, S., L. Mourier and H. Bergenholtz. 2006. English Dictionary of Accounting. Aarhus: Aarhus School of Business.

\section{Other literature}

Barz, I., H. Bergenholtz and J. Korhonen (Eds.). 2005. Schreiben, Verstehen, Übersetzen, Lernen. Frankfurt: Peter Lang.

Bergenholtz, H. and S. Tarp. 2005. Wörterbuchfunktionen. Barz, I., H. Bergenholtz and J. Korhonen (Eds.). 2005: 11-25.

Bergenholtz, H., S. Tarp and H.E. Wiegand. 1999. Datendistributionsstrukturen, Makro- und Mikrostrukturen in neueren Fachwörterbüchern. Hoffmann, L. et al. (Eds.). 1999 Fachsprachen. Ein internationales Handbuch zur Fachsprachenforschung und Terminologiewissenschaft/Lan- 
guages for Special Purposes. An International Handbook of Special-Language and Terminology Research: 1762-1832. Berlin/New York: Walter de Gruyter.

Busane, M. 1990. Lexicography in Central Africa: The User Perspective with Special Reference to Zaïre. Hartmann, R.R.K. (Ed.). 1990. Lexicography in Africa: 19-35. Exeter Linguistic Studies 15. Exeter: University of Exeter Press.

Gouws, R.H. 2004. Outer Texts in Bilingual Dictionaries. Lexikos 14: 67-88.

Gouws, R.H. Forthcoming. Op pad na 'n nuwe woordeboektipologie. Tydskrif vir Taalonderrrig.

Gouws, R.H. and M. Steyn. 2005. Integrated Outer Texts: A Transtextual Approach to Lexicographic Functions. Barz, I., H. Bergenholtz and J. Korhonen (Eds.). 2005: 127-136.

Hartmann, R.R.K. 1987. Four Perspectives on Dictionary Use: A Critical Review of Research Methods. Cowie, A.P. (Ed.). The Dictionary and the Language Learner: 11-28. Tübingen: Max Niemeyer.

Haugen, E. 1985. Lexicography and Language Planning. Jankowsky, K.R. (Ed.). Scientific and Humanistic Dimensions of Language: 571-580. Amsterdam: John Benjamins.

Hausmann, F.J. and H.E. Wiegand. 1989. Component Parts and Structures of General Monolingual Dictionaries: A Survey. Hausmann, F.J. et al. (Eds.). 1989-1991: 328-360.

Hausmann, F.J. et al. (Eds.). 1989-1991. Wörterbücher. Ein internationales Handbuch zur Lexikographie/Dictionaries. An International Encyclopedia of Lexicography/Dictionnaires. Encyclopédie internationale de lexicographie. Handbücher zur Sprach- und Kommunikationswissenschaft 5.1-5.3. Berlin: De Gruyter.

Herberg, D. 1989. Wörterbuchvorwörter. Hausmann, F.J. et al. (Eds.). 1989-1991: 750-754.

Kammerer, M. and H.E. Wiegand. 1998. Über die textuelle Rahmenstruktur von Wörterbüchern. Präzisierungen und weiterführende Überlegungen. Lexicographica 14: 224-238.

Nielsen, S. 2005. User's Guides. Barz, I., H. Bergenholtz and J. Korhonen (Eds.). 2005: 137-146.

Tarp, S. 2000. Theoretical Challenges to Practical Specialised Lexicography. Lexikos 10: 189-208.

Tarp, S. 2002. Basic Elements of Lexicographic Theory/Éléments de base de la théorie lexicographique. Emejulu, J. du P. (Ed.). 2003. Éléments de lexicographie gabonaise. Tome II: 7-35. New York: Jimacs-Hillman.

Wiegand, H.E. 1988. Was eigentlich ist Fachlexikographie? Mit Hinweisen zum Verhältnis von sprachlichem und enzyklopädischem Wissen. Munske, H.H. et al. (Eds.). Deutscher Wortschatz. Lexikologische Studien. Ludwig Erich Schmitt zum 80. Geburtstag von seinen Marburger Schülern: 729-790. Berlin: De Gruyter.

Wiegand, H.E. 1989. Der Begriff der Mikrostruktur: Geschichte, Probleme, Perspektiven. Hausmann, F.J. et al. (Eds.). 1989-1991: 409- 462.

Wiegand, H.E. 1996. Das Konzept der semiintegrierten Mikrostrukturen. Ein Beitrag zur Theorie zweisprachiger Printwörterbücher. Wiegand, H.E. (Ed.). 1996. Wörterbücher in der Diskussion II. Vorträge aus dem Heidelberger lexikographischen Kolloquium: 1-82. Lexicographica. Series Maior 76. Tübingen: Max Niemeyer.

Wiegand, H.E. 1998. Wörterbuchforschung. Untersuchungen zur Wörterbuchbenutzung, zur Theorie, Geschichte, Kritik und Automatisierung der Lexikographie. Berlin: De Gruyter.

Zgusta, L. 1971. Manual of Lexicography. Janua Linguarum Series Maior 39. Prague: Academia / The Hague/Paris: Mouton. 